\title{
MODULATORY EFFECT OF Drosera peltata J.E.Sm ON DEVELOPMENT OF METABOLIC SYNDROME IN TUMOR BEARING MICE
}

\author{
Raju Asirvatham ${ }^{1} *$, Seeja S $\operatorname{Raj}^{2}$, Arockiasamy Josphin Maria Christina ${ }^{3}$
}

\begin{abstract}
1Dept of Pharmacology, Sreekrishna College of Pharmacy and Research Centre, Parassala, Trivandrum, Kerala, India. 2Dept of Pharmaceutical Analysis, Sreekrishna College of Pharmacy and Research Centre, Parassala, Trivandrum, Kerala, India. 3Dept of Pharmacology, Nirmala college of Pharmacy, Muvattupuzha, Kerala, India.
\end{abstract}

Submitted: 02-07-2016

Revised: 20-09-2016

Accepted: 10-10-2016

*Corresponding author

Raju Asirvatham

Email:

rajuasirvatham@gmail.com

\begin{abstract}
The purpose of the study conducted was to know the extent of protection over the cancer associated metabolic syndrome development after administration of ethanol and aqueous extracts of Drosera peltata J.E.Sm against Dalton's ascites lymphoma (DAL) and Ehrlich's Ascites Carcinoma (EAC) bearing mice. Animals were divided into thirteen groups with a normal control, EAC control, DAL control, two groups with standard drug 5-Flurouracil $20 \mathrm{mg} / \mathrm{kg}+$ DAL \& EAC and eight groups with 250 and $500 \mathrm{mg} / \mathrm{kg}$ of ethanol and aqueous extracts of D.peltata J.E.Sm + EAC \& DAL, for respective cell lines. After $24 \mathrm{~h}$ of both tumor cell inoculations, animals were treated with extracts, once in a day for 14 days continuously. The indicators for the development of metabolic syndrome such as changes in blood glucose, serum hormone and lipid profile were found with both cell line bearing mice. Both ethanol and aqueous extracts of D.peltata J.E.Sm at doses of 250 and $500 \mathrm{mg} / \mathrm{kg}$ significantly reduced the elevated blood glucose, hormonal and lipid profile changes. These results confirmed that ethanol and aqueous extracts can stabilize the tumor induced hormonal, blood glucose and lipid profile changes in tumor bearing mice. This effect might be due to the presence of pharmacologically active phytoconstituents in extracts.
\end{abstract}

Keywords: Metabolic syndrome, Ehrlich's Ascites Carcinoma, Dalton's ascites lymphoma, Drocera peltata, anticancer

\section{INTRODUCTION}

The components of metabolic syndrome (MS) was described by National Cholesterol Education Program/Adult Treatment Panel III (NCEP-ATP III), the World Health Organization (WHO), the International Diabetes Federation (IDF) and the American Association of Clinical Endocrinologists (AACE) where is associated with type 2 diabetes mellitus, polycystic ovarian disease, non-alcoholic fatty liver disease (NAFLD), and possibly some cancers (Pooja et al., 2009). Different study reports supported that the MS, or its components, might play an important role in the ethiology and progression of certain cancer types and a worse prognosis for some cancers such as breast, endometrial, colorectal, pancreatic, hepatic and renal cancer (Sandra Braun et al., 2011). MS is a bunch of adiposity, hyperglycaemia, hypertension and dyslipidaemia. The additive or synergistic effects of the above components are key factors for cancer development and cancer related mortality. Abnormal body weight, inflammation and insulin resistance are interconnected where insulin resistant obese individuals are associated with secretion of tumor necrosis factor alpha (TNF- $\alpha$ ) from adipose tissue which affect the intracellular insulin signal cascade (hyperglycaemia). It is also associated with elevation in free fatty acid levels (dyslipidaemia), decrease in adiponectin levels, inhibition of peroxisome proliferator-activated receptor gamma by TNF- $\alpha$ and interleukin (IL)-1 stimulated with nuclear factor kappa B (NF- $x \mathrm{~B})$ (Uzunlulu et al., 2016). This leads to an abnormal variation of energy metabolism in cancer survivors and has become a hallmark syndrome for them. To overcome this increased energy requirements, tumor cells secrete cytokines/factors inducing muscle and 
fat degradation in cancer patients, a condition known as cancer cachexia which is the main cause of death, even in patients undergone drug treatments. Drug therapy with targeting devoid of cancer cachexia development is under research. A study reported that ketogenic diet supplied to cachectic phenotype altered metabolic condition, reduced tumor growth and inhibition of muscle and body weight loss (Surendra, et al., 2014).

The main approach for the treatment and prevention of MS in cancer is change in lifestyle and the next step is to treat the individual with their clinical manifestations (Pooja et al., 2009). The epidemiologic studies of MS to cancer are scarce and the reported study states that low levels of HDL are related with an augmented risk of malignancy. Similarly decreased level of serum low density lipoprotein is associated with the development of haematological cancer. High level triglyceride in serum is associated with increased risk of postmenopausal breast cancer and prostate cancer (Emily and Derek, 2013). Currently, there is no drug therapy for the symptomatic treatment of MS to cancer or as an entire disease. However widespread research endures to focus on this and have published lot of articles per year. These problems can be solved by naturopathic plant drug treatment where the treatment will help for the maintenance of normal metabolism, reduction of side effects and enhancement of body's immune system (Sanyal et al., 2002). In Ayurveda, the treatment comprises the use of entire plant extracts either alone or as a mixture of numerous plant extracts for better efficacy and reduction in toxicity. These herbal preparations contain variety of active constituents, which may function synergistically, causing therapeutic benefits and dropping the risks of adverse effects (Prachi et al., 2007). A plant with high flavonoid content with well-known anticancer property might be the best drug for the treatment of cancer associated MS (Raju et al., 2013a). An example for such a plant is D. peltata J.E.Sm, Droseraceae, which is a cosmopolitan, insectivorous plant. Among the 170 species, three plants are found in India, namely $D$. peltata J.E.Sm, D. indica L., and D. burmannii. Swarnabhasma is an Ayurvedic preparation which contains all the above three Drosera species. The genus Drosera contains plumbagin, naphthoquinones and flavonoids. It has been reported that it can be used for the treatment of bronchial disorders, diabetes mellitus, dyslipidaemia, tuberculosis, spasms, infections by various microbes, leprosy, malaria, cancer, leishmaniasis, fertility problems, CVS disorders such as arteriosclerosis, phthisis and also have immunomodulatory effect. The quercetin present in this plant is active against cancer (Raju et al., 2013b). From D. peltata J.E.Sm, 11 compounds were elucidated as isoshinanolone-4-O-beta-D-glucoside, isoshinanolone, epi-isoshinanolone, plumbagin, droserone, droserone-5-O-glucoside, quercetin, kaempferol, gossypetin-8-O-glucoside, 3,3'-dimethoxy ellagic acid, and ellagic acid. Extracts of plumbagin from Plum-bagineae and Droseraceae have long traditions of use in folk medicines in China and other Asian countries for the treatment of cancer, rheumatoid arthritis, dysmenorrhea and contusion of extremities (Robert et al., 2012). This present study is aimed to know the effect of ethanol and aqueous extract D. peltata J.E.Sm on protection over the cancer associated metabolic syndrome developed in tumor bearing mice.

\section{MATERIALS AND METHODS}

\section{Plant materials}

The entire plant of $D$. peltata J.E.Sm. was collected from Munnar hills, Kerala, India. Prof. K. Madhava Chetty, Taxonomist from S.V. University Andhra Pradesh, India, identified and authenticated this plant.

\section{Preparation of the extracts}

\section{Alcohol extract}

The weighed, shade dried powdered plant materials were extracted with $90 \% \mathrm{v} / \mathrm{v}$ ethanol in a Soxhlet extraction apparatus. The concentrated extract was suspended in distilled water for experimental use as EEDP (Ethanol extract of D. peltata J.E.Sm).

Aqueous extract

The marc which was obtained at the end of ethanol extraction was soaked in water for 48 hours to get the aqueous extract of $D$. peltata. This was concentrated under reduced pressure and was used as AEDP (Aqueous extract of $D$. peltata J.E.Sm). 
The ethanol (EEDP) and aqueous (AEDP) extracts of D. peltata were stored in air tight containers for further study.

\section{Induction of tumor using DAL and EAC cells}

Dalton Ascites Lymphoma (DAL) and Ehrlich's Ascites Carcinoma (EAC) cells were supplied by Amala Cancer Research Center, Thrissur, Kerala, India. The cells were maintained in vivo in Swiss albino mice by intraperitoneal transplantation. The tumor cells were injected intraperitoneally $\left(2 \times 10^{6}\right.$ cells per mouse) to animals of all groups except the first group.

\section{Determination of anticancer activity}

For the anticancer activity study (Raju et al., 2013a) Swiss Albino mice weighing 20-25g were kept in identical laboratory condition and were fed with standard pellet diet and water ad. libitum. Study protocol was approved by the Institution Animal Ethical Committee (Protocol. No: A. Raju 0903PH2254/JNTUH 2009). They were divided into thirteen groups (G1-G13) viz. Normal group(G1), DAL control group (G2), EAC control (G3), DAL $+20 \mathrm{mg} / \mathrm{kg}$ of 5Fluorouracil treated group (G4), EAC $+20 \mathrm{mg} / \mathrm{kg}$ of 5-Fluorouracil treated group (G5), DAL $+250 \mathrm{mg} / \mathrm{kg}$ EEDP treated (G6), DAL $+500 \mathrm{mg} / \mathrm{kg}$ EEDP treated (G7), EAC +250 $\mathrm{mg} / \mathrm{kg}$ EEDP treated (G8), EAC $+500 \mathrm{mg} / \mathrm{kg}$ EEDP treated (G9), DAL $+250 \mathrm{mg} / \mathrm{kg}$ AEDP treated (G10), DAL $+500 \mathrm{mg} / \mathrm{kg}$ AEDP treated (G11), EAC $+250 \mathrm{mg} / \mathrm{kg}$ AEDP treated (G12), $\mathrm{EAC}+500 \mathrm{mg} / \mathrm{kg}$ AEDP treated (G13) with six mice each, were used for the study. The DAL and EAC cells were injected intraperi-toneally ( $2 \mathrm{X} 10^{6}$ cells/mouse) to all groups of animals except G1. On the second day the animals of G4 and G5 were treated with 5- fluorouracil (20mg/kg, i.p), G6 to G9 were treated with 250 , $500 \mathrm{mg} / \mathrm{kg}$ of EEDP and G10 to G13 with 250, $500 \mathrm{mg} / \mathrm{kg}$ of AEDP orally. The treatment was continued for 14 days. G1 was treated with vehicle. On day 15 , blood was withdrawn by retro orbital plexus method, the mice were sacrificed and the following parameters were checked.

\section{Assessment of antitumor activity}

Tumor growth and development in DAL and EAC bearing mice are assessed by derived parameters such as body weight, packed cell volume (PCV), tumor cell count (viable), Mean survival time (MST), and Percentage increase in life span (\% ILS). On day 15, from the abdomen inoculated tumor cell lines were collected in a centrifuge tube and packed cell volume was measured. Viable cell count from suspension containing $100 \mu \mathrm{L}$ of cells were stained with $400 \mu \mathrm{L} 0.4 \%$ Trypan Blue using a hemocytometer. The live, unstained cells (live cells do not take up Trypan Blue) were counted in one set of 16 squares using a hand tally counter.

\section{Assay of hormones}

Mature female (virgin) Swiss Albino mice weighing 20-25g were used for the assay of hormone (Rezvanfar et al., 2008). LH, FSH, $\mathrm{E}_{2}$ and progesterone levels were measured from the blood serum (Anup et al., 2007).

\section{Lipid profile, blood glucose and liver enzymes}

Blood glucose, cholesterol, triglyceride, HDL cholesterol were estimated (Feinleib, 1983) using kits from Agappe Diagnostics, Kerala, India. Similarly estimation of Aspartate Aminotransferase (AST), Alanine Aminotransferase (ALT), Alkaline Phosphatase (ALP) Lactate Dehydrogenase (LDH) were also carried out on fully automated Analyzer Hitachi 717 (Italy).

\section{Statistical analysis}

The results were expressed as mean \pm S.E.M. The evaluation of the data was done using one way ANOVA followed by NewmanKeul's multiple comparison test; $\mathrm{p}<0.05$ implied significance.

\section{RESULT AND DISCUSSION}

The effect of EEDP and AEDP on tumor growth and development in DAL bearing mice (Table I), with respect to packed cell volume, cell counts (viable) and $\%$ ILS. Both the doses of extracts and $5 \mathrm{FU}$, significantly $(p<0.001)$ restored the body weight and cell count and was compared with tumor control group mice. Similarly \% ILS and MST were increased in extract treatment groups and was compared with 
Table I. Effect of EEDP and AEDP on tumor growth and development in DAL bearing mice

\begin{tabular}{|c|c|c|c|c|c|}
\hline Parameters & $\begin{array}{c}\text { Body } \\
\text { Weight (g) }\end{array}$ & $\begin{array}{l}\text { MST } \\
\text { (Days) }\end{array}$ & ILS (\%) & PCV (mL) & $\begin{array}{l}\text { Viable cell count } \\
\left(10^{6} \text { cells / mouse }\right)\end{array}$ \\
\hline Normal & $22.5 \pm 0.81$ & 40 & 100 & - & - \\
\hline DAL control & $35.43 \pm 1.34$ & $14 \pm 1.14$ & $36 \pm 2.81$ & $30.56 \pm 0.54$ & $7.16 \pm 1.45$ \\
\hline $\begin{array}{l}\text { DAL+5FU } \\
(20 \mathrm{mg} / \mathrm{kg})\end{array}$ & $22.63 \pm 0.75$ & $36.6 \pm 0.9$ & $91.5 \pm 2.32$ & $18.46 \pm 0.25$ & $0.68 \pm 0.12$ \\
\hline $\begin{array}{l}\text { DAL+EEDP } \\
250 \mathrm{mg} / \mathrm{kg}\end{array}$ & $23.7 \pm 0.8^{a}$ & $35.4 \pm 0.5^{\mathrm{a}}$ & $88.5 \pm 1.28^{a}$ & $25.6 \pm 1.5^{\mathrm{a}}$ & $0.48 \pm 0.11^{\mathrm{a}}$ \\
\hline $\begin{array}{l}\text { DAL+EEDP } \\
500 \mathrm{mg} / \mathrm{kg}\end{array}$ & $22.1 \pm 0.68^{a}$ & $39.4 \pm 0.5^{a}$ & $98 \pm 0.94 a$ & $27.02 \pm 0.65^{\mathrm{a}}$ & $0.3 \pm 0.11^{\mathrm{a}}$ \\
\hline $\begin{array}{l}\text { DAL+AEDP } \\
250 \mathrm{mg} / \mathrm{kg}\end{array}$ & $26.3 \pm 1.03^{a}$ & $32.8 \pm 0.86^{a}$ & $82 \pm 2.15^{a}$ & $27.3 \pm 0.66^{a}$ & $2.54 \pm 0.71^{a}$ \\
\hline $\begin{array}{l}\text { DAL+AEDP } \\
500 \mathrm{mg} / \mathrm{kg}\end{array}$ & $24.25 \pm 0.42^{\mathrm{a}}$ & $35 \pm 0.55^{a}$ & $86 \pm 0.61^{a}$ & $28.01 \pm 0.48^{a}$ & $1.9 \pm 0.18^{a}$ \\
\hline
\end{tabular}

These experimental outcomes indicated that the two doses of EEDP and AEDP exhibited inhibition of tumor cell growth on tumor cell inoculated mice.

Table II. Effect of EEDP and AEDP tumor growth and development in EAC bearing mice

\begin{tabular}{|c|c|c|c|c|c|}
\hline Parameters & $\begin{array}{c}\text { Body } \\
\text { Weight (g) }\end{array}$ & $\begin{array}{l}\text { MST } \\
\text { (Days) }\end{array}$ & ILS (\%) & PCV (mL) & $\begin{array}{l}\text { Viable cell count } \\
\left(10^{6} \text { cells / mouse }\right)\end{array}$ \\
\hline Normal & $22.55 \pm 1$ & 40 & 100 & - & - \\
\hline EAC control & $37.98 \pm 1.79$ & $11.4 \pm 0.5$ & $28.5 \pm 1.28$ & $30.56 \pm 0.54$ & $10.6 \pm 1.58$ \\
\hline $\begin{array}{l}\mathrm{EAC}+5 \mathrm{FU} \\
(20 \mathrm{mg} / \mathrm{kg})\end{array}$ & $22.1 \pm 0.89$ & $37.8 \pm 0.6$ & $94.5 \pm 1.66$ & $18.46 \pm 0.25$ & $0.76 \pm 0.17$ \\
\hline $\begin{array}{l}\text { EAC +EEDP } \\
250 \mathrm{mg} / \mathrm{kg}\end{array}$ & $24.35 \pm 1.6^{\mathrm{a}}$ & $35 \pm 0.5$ a & $87.5 \pm 1.37 \mathrm{a}$ & $25.6 \pm 1.5^{a}$ & $0.44 \pm 0.1$ a \\
\hline $\begin{array}{c}\text { EAC +EEDP } \\
500 \mathrm{mg} / \mathrm{kg}\end{array}$ & $23.3 \pm 0.29$ a & $36.8 \pm 0.86^{a}$ & $92 \pm 2.15^{a}$ & $27.02 \pm 0.65^{a}$ & $0.32 \pm 0.09$ a \\
\hline $\begin{array}{c}\text { EAC +AEDP } \\
250 \mathrm{mg} / \mathrm{kg}\end{array}$ & $25.3 \pm 0.29$ a & $35 \pm 1^{a}$ & $87.5 \pm 2.5^{\mathrm{a}}$ & $27.3 \pm 0.66^{a}$ & $2.52 \pm 0.5^{\mathrm{a}}$ \\
\hline $\begin{array}{c}\text { EAC +AEDP } \\
500 \mathrm{mg} / \mathrm{kg}\end{array}$ & $24.1 \pm 0.7^{\text {a }}$ & $35.2 \pm 0.37^{a}$ & $88 \pm 0.94$ a & $28.01 \pm 0.48^{a}$ & $1.82 \pm 0.17 \mathrm{a}$ \\
\hline
\end{tabular}

The data are expressed as mean \pm S.E.M. $n=6$. The data was analyzed by one way ANOVA followed by Newman-Keul's multiple comparison test. a- $\mathrm{p}<0.001$, compared to the tumor control group.

the tumor control group. The level of PCV was increased in tumor control mice and was normalised by extract treatment.

The data are mentioned as mean $\pm \mathrm{S}$. E. M. $\mathrm{n}=6$. The data was evaluated by one way ANOVA by using Newman-Keul's multiple comparison test. a- $\mathrm{p}<0.001$, compared to the tumor control group. Effective role of EEDP and AEDP on tumor growth and development in EAC bearing mice (Table II).
Oral administration of $250,500 \mathrm{mg} / \mathrm{kg}$ of EEDP and AEDP significantly $(p<0.001)$ increased the MST and \% ILS of EAC bearing mice whereas MST and \% ILS were decreased in second group mice. Similarly, there was an increase in body weight, PCV and viable cell count in tumor control group mice and were significantly $(p<0.001)$ decreased to near to normal by 14 days continuous administration of $250,500 \mathrm{mg} / \mathrm{kg}$ of EEDP and AEDP. 
Table III. Effect of EEDP and AEDP on lipid profile and blood glucose on EAC tumor cell bearing mice

\begin{tabular}{|c|c|c|c|c|c|}
\hline Groups & $\begin{array}{l}\text { Cholesterol } \\
(\mathrm{mg} / \mathrm{dL})\end{array}$ & $\begin{array}{c}\text { Triglyceride } \\
\text { (mg/dL) }\end{array}$ & $\begin{array}{c}\text { HDL } \\
(\mathrm{mg} / \mathrm{dL})\end{array}$ & $\begin{array}{c}\text { LDL } \\
(\mathrm{mg} / \mathrm{dL})\end{array}$ & $\begin{array}{l}\text { Blood glucose } \\
\quad(\mathrm{mg} / \mathrm{dL})\end{array}$ \\
\hline Normal & $142.89 \pm 2.19$ & $92.87 \pm 2.49$ & $39.78 \pm 0.21$ & $119.73 \pm 1.09$ & $110.6 \pm 1.23$ \\
\hline EAC Control & $107.03 \pm 1.22$ & $124.63 \pm 0.79$ & $27.73 \pm 0.71$ & $81.45 \pm 2.66$ & $214.3 \pm 4.45$ \\
\hline $\begin{array}{c}\mathrm{EAC}+5 \mathrm{FU} \\
(20 \mathrm{mg} / \mathrm{kg})\end{array}$ & $118.46 \pm 0.92$ & $88.23 \pm 1.19$ & $35.33 \pm 1.08$ & $116.98 \pm 0.9$ & $130.1 \pm 1.9$ \\
\hline $\begin{array}{c}\text { EAC + EEDP } \\
(250 \mathrm{mg} / \mathrm{kg})\end{array}$ & $130.5 \pm 0.2^{a}$ & $99.13 \pm 1.39^{a}$ & $32.08 \pm 0.64^{a}$ & $117.98 \pm 1.3^{\mathrm{a}}$ & $148.4 \pm 2.1^{\mathrm{a}}$ \\
\hline $\begin{array}{c}\text { EAC + EEDP } \\
(500 \mathrm{mg} / \mathrm{kg})\end{array}$ & $135.43 \pm 1.43^{a}$ & $93.6 \pm 1.93^{a}$ & $37.73 \pm 0.75^{a}$ & $127.5 \pm 0.57^{a}$ & $127.4 \pm 2.7$ a \\
\hline $\begin{array}{c}\text { EAC + AEDP } \\
(250 \mathrm{mg} / \mathrm{kg})\end{array}$ & $125.9 \pm 1.7 \mathrm{a}$ & $114.35 \pm 2.0^{\mathrm{a}}$ & $34.53 \pm 0.52^{a}$ & $106.8 \pm 1.14 a$ & $180.7 \pm 8.1^{b}$ \\
\hline $\begin{array}{c}\text { EAC + AEDP } \\
(500 \mathrm{mg} / \mathrm{kg})\end{array}$ & $134.98 \pm 1.52^{\mathrm{a}}$ & $104.18 \pm 0.9^{a}$ & $33.85 \pm 0.82^{a}$ & $113.7 \pm 1.45^{\mathrm{a}}$ & $137.2 \pm 5.2^{\mathrm{a}}$ \\
\hline
\end{tabular}

Table IV. Effect of EEDP and AEDP on lipid profile and blood glucose on DAL tumor cell bearing mice

\begin{tabular}{|c|c|c|c|c|c|}
\hline Parameters & $\begin{array}{l}\text { Cholesterol } \\
(\mathrm{mg} / \mathrm{dL})\end{array}$ & $\begin{array}{l}\text { Triglyceride } \\
\text { (mg/dL) }\end{array}$ & $\begin{array}{c}\text { HDL } \\
(\mathrm{mg} / \mathrm{dL})\end{array}$ & $\begin{array}{c}\text { LDL } \\
(\mathrm{mg} / \mathrm{dL})\end{array}$ & $\begin{array}{l}\text { Blood glucose } \\
(\mathrm{mg} / \mathrm{dL})\end{array}$ \\
\hline Normal & $154.45 \pm 5.12$ & $128.6 \pm$ & $36.65 \pm 0.39$ & $119.3 \pm 3.3$ & $110.6 \pm 1.23$ \\
\hline DAL Control & $122.68 \pm 3.7$ & $206.06 \pm 3.31$ & $23.55 \pm 0.81$ & $69.3 \pm 3.1$ & $263.7 \pm 8.3$ \\
\hline $\begin{array}{l}\text { DAL + 5FU } \\
(20 \mathrm{mg} / \mathrm{kg})\end{array}$ & 5 & 1 & 13 & 1.2 & 5 \\
\hline $\begin{array}{c}\text { DAL + EEDP } \\
(250 \mathrm{mg} / \mathrm{kg})\end{array}$ & $137.08 \pm 1.27^{\mathrm{b}}$ & $168.6 \pm 1.4^{\mathrm{a}}$ & $32.58 \pm 0.9$ a & $120.15 \pm 0.74^{a}$ & $128.6 \pm 3.4^{a}$ \\
\hline $\begin{array}{c}\text { DAL + EEDP } \\
(500 \mathrm{mg} / \mathrm{kg})\end{array}$ & $149.9 \pm 1.87^{a}$ & $153.86 \pm 1.3^{\mathrm{a}}$ & $36.13 \pm 0.88^{a}$ & $116.3 \pm 0.9^{a}$ & $117.5 \pm 2.6^{\mathrm{a}}$ \\
\hline $\begin{array}{c}\text { DAL + AEDP } \\
(250 \mathrm{mg} / \mathrm{kg})\end{array}$ & $130.58 \pm 3.69^{\mathrm{d}}$ & $175.4 \pm 0.8^{a}$ & $30.53 \pm 0.51^{a}$ & $107.55 \pm 2.29 a$ & $193.4 \pm 1.2^{\mathrm{b}}$ \\
\hline $\begin{array}{c}\text { DAL + AEDP } \\
(500 \mathrm{mg} / \mathrm{kg})\end{array}$ & $146.43 \pm 0.63^{a}$ & $170.95 \pm 1.5^{\mathrm{a}}$ & $32.7 \pm 1.01^{a}$ & $112.9 \pm 1.59^{a}$ & $149.3 \pm 5.8^{\mathrm{a}}$ \\
\hline
\end{tabular}

The data is mentioned as mean \pm S. E. M. $\mathrm{n}=6$. The data was evaluated by one way ANOVA by using Newman-Keul's multiple comparison test.a-p $<0.001$, compared to the tumor control group, b- $\mathrm{p}<0.01$, compared to the tumor control group.

An altered lipid profile and blood glucose level was found in EAC bearing mice (Table II). The continuous oral treatment for 14 days with $250,500 \mathrm{mg} / \mathrm{kg}$ of EEDP and AEDP in EAC bearing mice, restored the altered parameters, i.e; the serum cholesterol, HDL cholesterol and LDL cholesterol and showed significant $(\mathrm{p}<0.001)$ decrease in EAC control mice. In that, serum triglycerides and blood glucose values were significantly elevated in EAC control mice and were brought back to normal by the extract treatments, 250 and $500 \mathrm{mg} / \mathrm{kg}$ of EEDP and AEDP. 
Raju Asirvatham

Table V. Effect of EEDP and AEDP on serum hormone levels in virgin female bearing EAC cell line

\begin{tabular}{|c|c|c|c|c|}
\hline Parameters & $\begin{array}{c}\text { LH(ng/mL) } \\
\text { X10-2 }\end{array}$ & $\begin{array}{c}\text { FSH } \\
(\mathrm{ng} / \mathrm{mL})\end{array}$ & $\begin{array}{c}\mathrm{E}_{2}(ß-\text {-estradiol }) \\
\mathrm{pg} / \mathrm{m}\end{array}$ & $\begin{array}{c}\text { Progesterone } \\
(\mathrm{ng} / \mathrm{mL})\end{array}$ \\
\hline Normal & $21.45 \pm 1.17$ & $10 \pm 0.39$ & $24.9 \pm 0.29$ & $18.55 \pm 0.17$ \\
\hline EAC Control & $29.55 \pm 0.78$ & $4.65 \pm 0.15$ & $7.45 \pm 0.15$ & $6.63 \pm 0.33$ \\
\hline $\begin{array}{l}\text { EAC+ 5FU } \\
(20 \mathrm{mg} / \mathrm{kg})\end{array}$ & $19.83 \pm 1.6$ & $7.98 \pm 0.45$ & $22.55 \pm 1.15$ & $16.8 \pm 0.64$ \\
\hline $\begin{array}{c}\text { EAC+ EEDP } \\
(250 \mathrm{mg} / \mathrm{kg})\end{array}$ & $25.87 \pm 1.8^{\mathrm{d}}$ & $6.28 \pm 0.13^{\mathrm{b}}$ & $14.8 \pm 1.36^{\mathrm{a}}$ & $12.8 \pm 0.23^{\mathrm{a}}$ \\
\hline $\begin{array}{c}\text { EAC+ EEDP } \\
(500 \mathrm{mg} / \mathrm{kg})\end{array}$ & $24.63 \pm 0.23^{c}$ & $8.17 \pm 0.27 \mathrm{a}$ & $23.73 \pm 0.5^{a}$ & $17.73 \pm 0.15^{a}$ \\
\hline $\begin{array}{c}\text { EAC }+ \text { AEDP } \\
(250 \mathrm{mg} / \mathrm{kg})\end{array}$ & $27.88 \pm 1.06^{\mathrm{d}}$ & $4.95 \pm 0.23 \mathrm{~d}$ & $12.75 \pm 1.02^{\mathrm{a}}$ & $10.57 \pm 0.32^{a}$ \\
\hline $\begin{array}{c}\text { EAC+ AEDP } \\
(500 \mathrm{mg} / \mathrm{kg})\end{array}$ & $24.85 \pm 0.76^{c}$ & $6.3 \pm 0.16^{\mathrm{b}}$ & $14.8 \pm 1.34$ a & $14.88 \pm 0.36^{a}$ \\
\hline
\end{tabular}

Table VI. Effect of EEDP and AEDP on serum hormone levels in virgin female bearing DAL cell line

\begin{tabular}{|c|c|c|c|c|}
\hline Parameters & $\underset{\mathrm{X} 10^{-2}}{\mathrm{LH}(\mathrm{ng} / \mathrm{mL})}$ & $\begin{array}{c}\text { FSH } \\
(\mathrm{ng} / \mathrm{mL})\end{array}$ & $\begin{array}{c}\mathrm{E}_{2}(\text { (B-estradiol) } \\
\mathrm{pg} / \mathrm{mL}\end{array}$ & $\begin{array}{l}\text { Progesterone } \\
(\mathrm{ng} / \mathrm{mL})\end{array}$ \\
\hline Normal & $22.05 \pm 1.77$ & $8.68 \pm 0.3$ & $23.13 \pm 0.24$ & $17.73 \pm 0.14$ \\
\hline DAL control & $37.23 \pm 2.12$ & $3.57 \pm 0.18$ & $5.52 \pm 0.52$ & $6.8 \pm 0.23$ \\
\hline $\mathrm{DAL}+5 \mathrm{FU}$ & $18.43 \pm 0.45$ & $8.25 \pm 0.33$ & $21.65 \pm 0.85$ & $16.8 \pm 0.22$ \\
\hline $\begin{array}{c}\text { DAL+EEDP } \\
(250 \mathrm{mg} / \mathrm{kg})\end{array}$ & $22.8 \pm 1.56^{a}$ & $6.1 \pm 0.09$ а & $15.23 \pm 0.98$ a & $12.55 \pm 0.21$ a \\
\hline $\begin{array}{c}\text { DAL+ EEDP } \\
(500 \mathrm{mg} / \mathrm{kg})\end{array}$ & $23.4 \pm 0.67$ a & $7.58 \pm 0.17 \mathrm{a}$ & $23.88 \pm 0.74$ a & $17.28 \pm 0.48^{a}$ \\
\hline $\begin{array}{c}\text { DAL+ AEDP } \\
(250 \mathrm{mg} / \mathrm{kg})\end{array}$ & $27.43 \pm 0.26^{a}$ & $4.95 \pm 0.23$ a & $9.35 \pm 0.39$ a & $10.67 \pm 0.2^{a}$ \\
\hline $\begin{array}{c}\text { DAL+ AEDP } \\
(500 \mathrm{mg} / \mathrm{kg})\end{array}$ & $25.35 \pm 0.69 \mathrm{a}$ & $5.95 \pm 0.06^{a}$ & $14.05 \pm 0.63 \mathrm{a}$ & $14.85 \pm 0.33^{a}$ \\
\hline
\end{tabular}

Table IV shows the blood glucose and lipid profile of DAL bearing mice, where the cholesterol, HDL and LDL level showed significant $(\mathrm{p}<0.001)$ decrease in DAL control mice and were restored by the doses of 250 , $500 \mathrm{mg} / \mathrm{kg}$ of EEDP and AEDP, whereas, the serum triglyceride and blood glucose values were significantly elevated in DAL control mice and were brought back to normal by the extract treatment. However, $250 \mathrm{mg} / \mathrm{kg}$ of AEDP was less significant $(\mathrm{P}<0.05)$ in normalization of cholesterol level.
The continuous oral administration for 14 days with 250 and $500 \mathrm{mg} / \mathrm{kg}$ of EEDP and AEDP restored the hormone level near to normal in female virgin mice bearing EAC cell line. The altered hormonal levels in virgin (Table V), where $250 \mathrm{mg} / \mathrm{kg}$ of AEDP and AEDP were not significant $(P>0.05)$ in restoration of $\mathrm{LH}$ and less significant $(\mathrm{P}<0.01)$ to FSH and $\mathrm{E}_{2}$. Also $500 \mathrm{mg} / \mathrm{kg}$ of EEDP and AEDP showed less significant $(\mathrm{P}<0.01)$ effect on $\mathrm{LH}$ level in EAC bearing mice. Lower dose 
of AEDP $(250 \mathrm{mg} / \mathrm{kg})$ was not significant $(\mathrm{P}>0.05)$ on $\mathrm{FSH}$ restoration.

The data is mentioned as mean $\pm \mathrm{S}$. E. M. $\mathrm{n}=6$. The data was evaluated by one way ANOVA by using Newman-Keul's multiple comparison test. a-p $<0.001$, compared to the tumor control group, $\mathrm{b}-\mathrm{p}<0.01$, compared to the tumor control group, $\mathrm{c}-\mathrm{p}<0.05$, compared to the tumor control group, $\mathrm{d}-\mathrm{p}>0.05$ compared to the tumor control group.

The serum hormone levels in virgin female mice of DAL bearing mice were greatly altered (Table VI). An increased LH level was found in DAL control group mice. The continuous oral administration for 14 days with 250 and $500 \mathrm{mg} / \mathrm{kg}$ of EEDP and AEDP significantly $(\mathrm{p}<0.001)$ restored the $\mathrm{LH}, \mathrm{FSH}$, $\mathrm{E} 2$ and progesterone level in female virgin mice bearing DAL cell line.

The data is mentioned as mean \pm S. E. M. $\mathrm{n}=6$. The data was evaluated by one way ANOVA by using Newman-Keul's multiple comparison test. a-p $<0.001$, compared to the tumor control group.

Metabolic syndrome (MS) plays a significant role in the progression of cancer which includes hypertriglyceridemia, low serum HDL level, etc. There is an epidemiological survey supporting that, a persons with MS are more prone to get colon cancer. Earlier preclinical animal study report revealed that soy and tea combination delayed the progression and the growth of breast and prostate tumour. The study also suggested that bioactive component which was present in soy and tea might have strong cancer prevention activity via the prevention of metabolic irregularities (Zhou et al., 2007). Based on the above hypothesis, this study has been conducted to evaluate the cancer development prevention and protection over the cancer associated metabolic syndrome in tumor bearing mice by using species of carnivorous plant Drosera in India.

Tumor growth response was evaluated by change in body weight, PCV, tumor cell count, MST, and \% ILS of cancer control mice was compared with extract treatment groups. In both DAL and EAC-bearing mice, ascites fluid volume increased progressively. This ascites fluids act as a nutritional supplement for tumor cell growth and development. This fluid volume was high which reflected their body weight in both DAL and EAC control mice (Malaya et al., 2004). Both the ethanol and aqueous extracts of DB, DP, and DI reduced the tumor growth and development of tumor in mice.

Metabolism of glucose and its utilization are generally regulated by certain herbs and spices through their signalling pathways. High triglycerides level, low HDL and high LDL, elevated level of blood pressure, incidence of insulin resistance, and increased level of proinflammatory markers and proteins in plasma are the characteristic for MS. A subject showing 3 or more than three of the above characteristics plus insulin resistance is generally considered to have the MS. Plants with polyphenols and flavonoids have antioxidant, anti-inflammatory and hypoglycaemic potential which play an important role in reducing risk factors which are associated with development of metabolic syndrome (Kiran, 2013). In this study also, the plant genus Drosera contains plumbagin, naphthoquinones and flavonoids, which reduce the elevated blood sugar level in tumor bearing mice to normal.

In cancer cachexia, reduction in body weight is due to exhaustion of body fat. Triglyceride, the major storage form of fat, is converted to glycerol and free fatty acids (FFA) by hydrolytic metabolism. This causes hyperlipidaemia and is associated with some tumors. In certain cancers, there is an association between weight loss and reduction of enzyme activity. When compared to normal person, cancer patient's body energy requirements are provided by fat which are mobilized and oxidized in a greater extent which leads to low HDL and high triglycerides; these lipid abnormalities also can be observed in type 2 diabetes (Gallagher and LeRoith, 2013, Douglas and Shaw, 1990). In the present study, an increased level of triglyceride and low level of HDL were observed in tumor control mice and were restored after continuous oral administration for 14 days with EEDP and AEDP.

Researchers have also reported that there is an increase in risk of cancer development in those with increased level of endogenous sex hormones and gonadotrophic hormones with 
respect to increase in number of receptor. Estrogen and progesterone are steroid hormones which support tumorigenesis process. Luteinizing hormone (LH) and follicle stimulating hormone (FSH) are involved in the regulation of steroidogenesis (Anup et al., 2007). In this study EAC and DAL bearing virgin female mice showed altered hormone levels which were brought back to the normal by the extract treatment (except for the lower dose of AEDP).

\section{ACKNOWLEDGEMENTS}

The authors gratefully acknowledge K M College of Pharmacy for providing support and facilities for this research work. The authors also thank Dr. S.N Yoganarasimhan for his guidance in the selection and collection of plant material.

\section{REFERENCES}

Anup M., Sandip K., Batabyal Mrinal KP., 2007. Long- term caffeine induced inhibition of EAC cell progression in relation to gonadal hormone status. Indian J Exp Biology. 45: 347-352.

Douglas RG., Shaw JHF., 1990. Metabolic effects of cancer: Review. Br J Surg. 77: 246-254.

Emily JG., Derek L., 2013. Epidemiology and Molecular Mechanisms Tying Obesity, Diabetes, and the Metabolic Syndrome with Cancer. Diabetes care. 36: S233-239.

Feinleib M., 1983. Review of the epidemiological evidence for a possible relationship between hypocholesterolemia and cancer. Cancer Res. 43: 2503-2507.

Gallagher EJ., LeRoith D., 2013. Epidemiology and Molecular Mechanisms Tying Obesity, Diabetes, and the Metabolic Syndrome with Cancer. Diabetes Care. 36(Suppl 2):S233-S239.

Kiran SP., 2013. Beneficial effects of herbs, spices and medicinal plants on the metabolic syndrome, brain and cognitive function. Cent. Nerv. Syst. Agents Med. Chem. 13: 13-29.

Malaya Gupta., Upal KM., Ramanathan SK., Thangavel S., Madgula LMV., 2004. Antitumor Activity and antioxidant status of Caesalpinia bonducella against
Ehrlich Ascites Carcinoma in Swiss albino mice. J Pharmacol Sci. 94: 177-184.

Pooja P., Sushil KJ., Subhashini Y., 2009. Metabolic Syndrome and Cancer. Metabolic syndrome and related disorders. 7(4):279-288.

Prachi G., Haruyo I., Nikita M., Gautam S., Bharat BA., 2007. Ancient medicine to modern medicine: Ayurvedic concepts of health and their role in inflammation and cancer. I Soc for Integrative Oncology. 5:1-16.

Raju A., Christina AJM., Anita Murali., 2013b. In Vitro Antioxidant and anticancer activity studies on Drosera indica L. (Droseraceae). Adv Pharm Bull. 3(1): 115-120.

Raju A., Christina AJM., Anita Murali., 2013a. Effect of Drosera burmannii vahl on metabolic syndrome developed in Ehrlich Ascites Carcinoma (EAC) bearing mice. Phytopharmacology. 4(1): 53-60.

Rezvanfar MA., Sadrkhanlou RA., Ahmadi A., Shojaei-Sadee H., et al., 2008. Protection of cyclophosphamide-induced toxicity in reproductive tract histology, sperm characteristics, and DNA damage by an herbal source; evidence for role of freeradical toxic stress. Human Experimental Toxicology. 27: 901-910.

Robert G., Barry J., Conn JJ., Bruhl., 2012. Morphological evaluation of the Drosera peltata complex (Droseraceae). Aust Syst Bot. 25: 49-80.

Sandra B., Keren BW., Derek Le R., 2011. The Link between the Metabolic Syndrome and Cancer.Int J Biol Sci. 7(7): 1003-1015.

Uzunlulu M., Telci CO., Oguz A., 2016. Association between Metabolic Syndrome and Cancer. Ann Nut.Metab.68:173-179.

Sanyal U., Samanta S., Pain A., Datta S., 2002. Interleukin $-4,-5$ and -13 emerging therapeutic targets in allergic disease. $J$ Exp Clin. Cancer Res. 21: 609.

Surendra KS., Teklab G., Vinee P., Nina VC., et al., 2014. Metabolic reprogramming induced by ketone bodies diminishes pancreatic cancer cachexia. Cancer Metab. 2: 18.

Zhou JR., Li L., Pan W., 2007. Dietary soy and tea combinations for prevention of breast and prostate cancers by targeting metabolic syndrome elements in mice. American J Clin nut. 86(3): s882-s888. 